\title{
ZBIEG WIELU PRZYPADKÓW W „CIĄGU SZCZEGÓLNYCH OKOLICZNOŚCI” JAKO KATALIZATOR ZAINTERESOWAŃ BADAWCZYCH PROF. DR. HAB. ANDRZEJA KWILECKIEGO ${ }^{1}$
}

Za każdym rogiem czyha kilka nowych kierunków.

Stanisław Jerzy Lec

Intrygująco brzmiąca tytułową rolę ciagu szczególnych okoliczności w pojawianiu się kolejnych obszarów socjologicznej penetracji w życiorysie naukowym przybliżył i zrelacjonował senior polskich socjologów prof. dr hab. Andrzej Kwilecki podczas spotkania w poznańskim Pałacu Działyńskich, promującego kolejną w Jego bogatym dorobku publikacyjnym książkę, zatytułowana $Z$ pogranicza socjologii $i$ historii. Elementy warsztatu badawczego ${ }^{2}$.

Zanim doszło do tego „wyznania metodologicznego”, wypełniający szczelnie salę słuchacze poznali długą listę faktów biograficznych powiązanych z kolejnymi etapami działalności naukowej i społecznej Profesora. Dzięki finezyjnemu i drobiazgowemu wprowadzeniu prof. dr hab. Anny Wolff-Powęskiej, uzupełnionemu przez prof. dr. hab. Witolda Molika, badacza dziejów polskiej inteligencji i ziemiaństwa, oraz komentarzowi prof. A. Kwileckiego, jak również zawartości promowanej książki - dane było osobom obecnym na spotkaniu poznać punkty zwrotne w ciagu szczególnych okoliczności, które zarówno kształtowały osobowość Profesora, jak i zadecydowały o Jego zainteresowaniu się tymi sferami i przejawami życia społecznego, które znalazły się w punktach przecięcia osobistych losów życiowych z wydarzeniami historycznymi dwudziestowiecznej Polski i Europy.

Najpierw był Kwilcz i szczęśliwe, w ocenie Profesora, dzieciństwo spędzone w rodzinnym majątku, przerwane okupacją hitlerowską i koniecznościa przeniesienia się wraz matką i starszą siostrą do uzdrowiskowej miejscowości Iwonicz na Ziemi Sanockiej, będącej ówcześnie własnością Załuskich, rodziny

${ }_{1}^{1}$ Andrzej Chryzostom Kwilecki, prawnik i socjolog, urodzony 23 października 1928 r. w Kwilczu w dobrach rodzinnych leżących na trasie z Poznania do Gorzowa; od 1958 r. pracownik naukowy w poznańskim Instytucie Zachodnim. Od 1972 do 1981 r. dyrektor Instytutu Socjologii UAM, a w latach 1982-1984 prorektor tegoż Uniwersytetu oraz kierownik Zakładu Historii Socjologii w Instytucie Socjologii (1986-1988). Był także wykładowcą francuskiej École des hautes études en sciences sociales i przewodniczacym Komitetu Nauk Socjologicznych Polskiej Akademii Nauk. Pracował nadto w Zakładzie Badań Narodowościowych PAN oraz w Wyższej Szkole Nauk Humanistycznych i Dziennikarstwa w Poznaniu.

${ }^{2}$ Wydawnictwo Nauka i Innowacje, Poznań 2016. Spotkanie, które odbyło się 29 września 2016 r., zorganizował prof. dr hab. Ryszard Wryk, prezes Wydawnictwa Nauka i Innowacje. 
ze strony matki Profesora (1939-1944). Po wielu latach A. Kwilecki bardzo wysoko ocenił socjalizującą rolę obu ważnych w dorastaniu miejsc, pisząc:

[...] po Kwilczu, miejscu urodzenia, mojej pierwszej ojczyźnie lokalnej, Iwonicz stał się moja drugą ojczyzna lokalna, w której przeżyłem wojenne, bardzo przykre i trudne, ale ważne lata młodzieńcze we względnie dobrych warunkach, w bliskim otoczeniu rodziny Załuskich, w kontaktach ze znajomymi przyjaciółmi rodziny, mając dostęp do bogato zaopatrzonej biblioteki uzdrowiskowej oraz płytoteki z licznymi nagraniami muzyki poważnej i rozrywkowej ${ }^{3}$.

Podbeskidzie zaznaczyło się także w życiorysie A. Kwileckiego ukończeniem dwóch klas gimnazjalnych w ramach tajnego nauczania prowadzonego przez Gimnazjum i Liceum w Krośnie oraz poznaniem zasad gry w szachy, wymagającej spokoju, wyobraźni i przenikliwości oraz zdolności przewidywania kilku ruchów do przodu. Rozwijane w następnych latach walory myślenia i działania szachisty ${ }^{4} \mathrm{z}$ całą pewnością przydały się w późniejszej pracy badawczej, a także wówczas, gdy trzeba było wypracować strategię życiową w nowych warunkach ustrojowych PRL, które przyniosły ziemiaństwu polskiemu prześladowania oraz konfiskatę dóbr (utrata przez Polskę Kresów Wschodnich, przesiedlenia, reforma rolna), a także - co równie istotne - skazanie tej warstwy społecznej na zapomnienie ${ }^{5}$.

Po zakończeniu wojny i krótkim pobycie w Krośnie A. Kwilecki przeniósł się na dłuższy czas do Krakowa, gdzie wznowił naukę, natomiast studia prawnicze i socjologiczne ukończył w Poznaniu. Skierowany nakazem pracy do jednej z poznańskich szkół podstawowych, po czterech latach dzięki kolejnemu zbiegowi szczególnych okoliczności $i^{6}$, A. Kwilecki trafia do Instytutu Zachodniego, jako pracownik naukowy Sekcji Socjograficznej, przekształconej w okresie późniejszym w Zakład Socjologii, którego kadra prowadziła pionierskie badania socjograficzne i historyczne dziejów osadnictwa na Ziemi Lubuskiej i Pomorzu Zachodnim. Profesor włączony został natychmiast w program unikatowych badań terenowych opartych na analizie dokumentów urzędowych, wielokrotnych kontaktach z powstającymi instytucjami i napływającymi migrantami, obserwacji uczestniczącej. Wieloletnim obserwacjom rodzącego się społeczeństwa Ziem Za-

${ }^{3}$ „Mój” Iwonicz, w: A. Kwilecki, Z pogranicza socjologii..., s. 83.

${ }^{4}$ „Tam [w Iwoniczu] zainteresowałem się szachami. Podstawowy materiał znajdowałem w cotygodniowej obszernej rubryce ukazujaccej się na łamach »Gońca Krakowskiego« od listopada 1942 do stycznia 1945 r. Rosnący z tygodnia na tydzień zbiór tych kącików stał się dla mnie głównym podręcznikiem do historii i teorii szachów”. W latach 40. i 50. ubiegłego wieku A. Kwilecki czterokrotnie grał w finałach szachowych mistrzostw Polski. W latach 1952-1956 pod patronatem „Gazety Poznańskiej” przeprowadził trzykrotnie korespondencyjne mistrzostwa Wielkopolski. W 1954 r. zainicjował zorganizowanie pierwszego w Poznaniu masowego turnieju błyskawicznego, który zgromadził setki uczestników. W latach 1952-1960 publikował szachowe artykuły i notatki na łamach „Gazety Poznańskiej” i „Expressu Sportowego”, jak również w „Szachach”, a w 1990 r. wydał książkę: Szachy w Poznaniu. Sto pięćdziesiąt lat, Wydawnictwo Poznańskie, Poznań. Nie bez powodu mówiono zatem: PROFESOR - NIE TYLKO SZACHÓW (Fenomen doktora K., „Szachy” 1993, nr 11 i 12).

${ }^{5}$ Piszacy te słowa dowiadywał się w peerelowskiej szkole prawie wyłącznie o hulaszczym życiu, zdrajcach interesu narodowego, kosmopolityzmie, złym traktowaniu poddanych itp. wynaturzeniach „klasy panów” - na szczęście sąsiedztwo z ziemiańską rodziną z Wołynia umożliwiło mi poznawanie faktów weryfikujących „prawdy historyczne” nowej władzy.

${ }^{6}$ Propozycja zatrudnienia wyszła od dr. Zygmunta Dulczewskiego (studencka znajomość) i stanowiła, jak się później okazało, istotny zwrot w życiu zawodowym Profesora. 
chodnich towarzyszyły analizy niezwykle wartościowych poznawczo materiałów pochodzących z konkursów pamiętnikarskich, rozpisywanych wśród osadników, dzięki którym możliwe było odtwarzanie procesu formalnej i społecznej organizacji osadnictwa, zarówno przesiedleńczego, jak i związanego z reemigracja z krajów zachodnich i repatriacją z kresów wschodnich II RP, a także niekontrolowanego, żywiołowego napływu ludności (uchodzący przed prześladowaniami, „poszukiwacze przygód”, a także tzw. szabrownicy). Unikatowe materiały pamiętnikarskie umożliwiły odtwarzanie struktury ludności osiedleńczej i rodzimej Ziem Zachodnich, opis ról i profili społecznych ich mieszkańców, poznanie wzajemnych wizerunków oraz zachodzących w ich obrębie zmian.

Zbiegiem szczególnych okoliczności kolejne badania prowadzone w Instytucie Zachodnim wśród Łemków osiedlonych na Ziemiach Zachodnich ${ }^{7}$ przecięły się także z iwonickim światem społecznym dorastającego Andrzeja Kwileckiego, który tam właśnie zetkną się z kulturą łemkowską.

Uzyskanie w 1965 r. stypendium francuskiego zaowocowało otwarciem nowego w polskich warunkach obszaru badań ówczesnego stanu integracji europejskiej „u źródeł”, w instytutach naukowych we Francji, Szwajcarii oraz Belgii, dzięki czemu polski czytelnik otrzymał wiedzę przybliżajaccą przesłanki, bazę ideologiczną oraz istotę postępującego procesu jednoczenia się Europy, wówczas jeszcze wyłącznie jej części zachodniej ${ }^{8}$. Mimo krótkiego, raptem czteromiesięcznego, pobytu we Francji i intensywnej pracy badawczej nad problemami integracji europejskiej, Profesor znalazł jeszcze czas na to, by po paryskiej kwerendzie bibliotecznej przypomnieć polskim socjologom udział rodaków w pracach utworzonego w 1894 r. Międzynarodowego Instytutu Socjologicznego w Paryżu (m.in. L. Gumplowicza, L. Petrażyckiego, K. Kelles-Krauza, F. Znanieckiego), instytucji o niezwykle rozbudowanych zadaniach na rzecz rozwijajacej się, nowej dyscypliny naukowej ${ }^{9}$.

Wyobraźnia socjologiczna, wsparta przenikliwością badawczą prof. A. Kwileckiego, przejawiła się ponownie w przebiegu kariery zawodowej w momencie otwarcia granicy dla ruchu turystycznego między Polską i NRD pod koniec 1971 r. Profesor dostrzegł kolejny po badaniach osadnictwa na Ziemiach Zachodnich „wielki temat”, będący wyjątkową dla socjologa szansą obserwowania swoistego społecznego eksperymentu naturalnego in statu nascendi i zapropo-

7 Badania terenowe zainicjowane w latach 1958-1959, kontynuowane były w 1962 r. z wykorzystaniem wielu technik: wywiadu z dorosłymi i dziećmi oraz nauczycielami, techniki analizy dokumentów urzędowych dotyczących osadnictwa Łemków oraz działalności organizacji łemkowskich, a także analizy materiałów prasowych. Badania zaowocowały obronioną w roku 1964 pracą doktorska, która w wyniku ingerencji cenzury ukazała się dopiero po dziesięciu latach (A. Kwilecki, Łemkowie. Zagadnienia migracji i asymilacji, PWN, Warszawa 1974).

${ }^{8}$ Wyniki naukowe tej pierwszej zagranicznej podróży zawarł dr A. Kwilecki w opublikowanej w roku 1969 przez Wydawnictwo Poznańskie pracy habilitacyjnej: Idea zjednoczenia Europy. Polityczno-socjologiczne aspekty.

9 „Do zadań tych należało utrwalanie i rozwijanie socjologii jako osobnej dyscypliny naukowej; teoretyczne ustalenie wzajemnych stosunków i współzależności między socjologią i innymi naukami społecznymi; wprowadzenie socjologii jako przedmiotu nauczania do uniwersytetów oraz innych szkół i instytutów; pobudzanie życia naukowego i popieranie uczonych organizujacych instytucje socjologiczne w innych krajach; stworzenie płaszczyzny dla międzynarodowych kontaktów i wymiany informacji w dziedzinie socjologii” (Kontakty polskich uczonych z Międzynarodowym Instytutem Socjologicznym w Paryżu, w: A. Kwilecki, Z pogranicza socjologii..., s. 55). 
nował Wydziałowi I Nauk Społecznych PAN przeprowadzenie badania zmian społecznych zachodzacych po obu stronach granicy zachodniej. Uzyskawszy zgodę i środki na badania ${ }^{10}$, dziewięciu pracowników poznańskiego Instytutu Zachodniego w kwietniu 1972 r. przeprowadziło oryginalny metodologicznie, bogaty w techniki i narzędzia zwiad socjologiczny ${ }^{11} \mathrm{w}$ rejonie przygranicznym (Słubice, Gubin, Zgorzelec, Świecko, Frankfurt nad Odra, Guben, Görlitz) oraz w miejscowościach oddalonych od granicy (m.in. Zielona Góra, Berlin) ${ }^{12}$. Kilkumiesięczne, intensywne badania umożliwiły opracowanie w kwietniu $1972 \mathrm{r}$. przez prof. A. Kwileckiego obszernego raportu ${ }^{13}$ dla PAN, który przekazany został w nieco zmienionej wersji z klauzula „poufne” najwyższym władzom państwowym. Raport był najobszerniejszym i najwcześniejszym opisem sytuacji po obu stronach granicy w okresie najbardziej żywiołowego, spontanicznego ruchu transgranicznego $0^{14}$, „prezentując obraz realny i rzetelny, podkreślający naturalnie pozytywy, ale nie uciekający przed - nawet bolesnymi i gorzkimi stronami negatywnymi" 15 .

Doświadczenia dzieciństwa i młodości, losy rodzinne oraz silne poczucie tożsamości społecznej powracają u prof. A. Kwileckiego narastajacym przez lata przekonaniem o obowiązku przywracania zbiorowej pamięci roli i znaczenia polskiego i wielkopolskiego ziemiaństwa w kulturze i życiu publicznym ${ }^{16}$. Zadaniu temu poświęcił się jednak Profesor całkowicie i - jak stwierdził -

10 Istotną rolę odegrał w tej sprawie prof. Władysław Markiewicz, ówczesny sekretarz Wydziału I PAN, dając przedsięwzięciu „parasol polityczny” z racji pełnionych funkcji politycznych.

${ }^{11}$ Obok wywiadów kwestionariuszowych i swobodnych prowadzonych z Polakami i Niemcami, materiałów pochodzących od uczniów szkół w Słubicach i Gubinie oraz z obserwacji w kilku wsiach i miastach po obu stronach granicy i spotkań z przedstawicielami handlu i gastronomii, instytucji publicznych, prowadzono także obserwację uczestniczącą w pociągach z Poznania do Frankfurtu nad Odrą i Berlina.

12 Badania rozpoczęte w Instytucie Zachodnim kontynuowane były w kierowanym przez prof. A. Kwileckiego od roku 1972 Instytucie Socjologii UAM - wśród kontynuatorów byli profesorowie Zygmunt Dulczewski, Stanisław Lisiecki i Leszek Gołdyka, a także dr Maria Błaszczyk, dr Barbara Pawłowska oraz mgr Teresa Kramer.

13 Zwiad badawczy przeprowadzony w 1972 roku na pograniczu Polska-NRD, w: A. Kwilecki, Z pogranicza socjologii..., s. 29-44.

14 Tylko w jednym kierunku - z Polski do NRD wzrósł on w 1972 r. prawie pięćdziesięciokrotnie, w 1971 r. bowiem Niemcy wschodnie odwiedziło 197 tys. obywateli polskich, a w 1972: 9468 260. W przypadku NRD, startującej ze znacznie wyższego poziomu (w 1971 r. przyjechało do Polski 537 tys. Niemców) wzrost był dwunastokrotny - do 6763419 (ale i tak co trzeci statystyczny obywatel NRD odwiedził wschodniego sąsiada). Tylko podczas wakacji - od początku lipca do 20 sierpnia - do Polski przyjechało 1876 tys. Niemców, a do NRD 1915,5 tys. Polaków (Socjologiczny zwiad po otwarciu granic PRL-NRD, opracował: Jerzy Kochanowski, „Polski Przegląd Dyplomatyczny" 1, 2(2), 2001, s. 22 i 29).

${ }_{15} \mathrm{~W}$ rok po otwarciu granicy powstał raport STASI pt. „Informacja o wzroście negatywnych reakcji na utrzymanie poziomu handlu i zaopatrzenia w określonych centrach bezwizowych podróży obywateli PRL do NRD”, który kończył się apelem o jak najszybsze rozwiązanie problemu polskich „turystów”. W rezultacie strona polska zaczęła ściśle reglamentować wymianę pieniędzy, NRD zaś wprowadziła restrykcje celne na towary, przede wszystkim na najbardziej dotowane. W rezultacie w 1973 r. wyjechało do NRD trzy miliony mniej Polaków, ibidem, s. 26.

16 „Przez kilka lat nurtowała mnie myśl o podjęciu problematyki w pewnym sensie dla mnie naturalnej; za taką uznałem problematykę ziemiaństwa polskiego, [...] do której podjęcia byłem w pewnym stopniu przygotowywany już od lat młodości” („Mój” Iwonicz, w: A. Kwilecki, Z pogranicza socjologii..., s. 79 i 82). 
$z$ wielka przyjemnościa dopiero po przejściu na emeryturę ${ }^{17}$, podejmując benedyktyńską wręcz pracę nad „gromadzeniem i wykorzystywaniem dokumentacji faktograficznej; wydobywaniem z zapomnienia i opisywaniem osób, rodzin, wydarzeń mogących mieć znaczenie dla historii społecznej; uwzględnianiem punktu widzenia historycznego i łączenia go z analizą typu socjologicznego"18. W rezultacie w latach 1993-2012 polskie piśmiennictwo wzbogaciło się o 13 publikacji zwartych poświęconych ziemiaństwu oraz 214 artykułów prasowych przybliżajacych w atrakcyjnej narracyjnie formie socjograficzne sylwetki wielkopolskich ziemian $\mathrm{w}$ ich społecznym otoczeniu ${ }^{19}$. Profesor swoimi publikacjami przybliżył współczesnym ten niewątpliwy fenomen socjologiczny, jakim było utrzymanie, mimo terytorialnego rozproszenia rodów ziemiańskich, zacieśnienia więzi rodzinnych, przekazanie wzorów kulturowych i tradycji narodowych i znaczącej roli kobiet w tym procesie oraz wykazanie zdolności przystosowawczych ziemiaństwa ${ }^{20}$, nabytych w ramach „systemu wychowawczego panujaccego w dworach i pałacach, opartego na stałym rytmie życia, dyscyplinie, kultywowaniu tradycji, szacunku dla wiedzy, wdrażaniu do regularnego wykonywania obowiązków"21.

Doniosłość i walory dokumentacyjne, analityczne i popularyzatorskie tej części dorobku naukowego Profesora dobrze oddaje opinia jednego z recenzentów, piszącego, że nie był On „[...] obserwatorem z zewnątrz i nie próbuje odtwarzać nie istniejacego świata. On ten świat nosi w sobie"22.

Autorskie w zamierzeniu spotkanie, przez swój retrospektywny charakter, było w rzeczywistości benefisem prof. dr. hab. Andrzeja Kwileckiego dla uczczenia Jego długoletniej działalności naukowej, społecznej i publicznej23, uhonorowaniem wkładu do polskiej socjologii oraz pozostawania wiernym

${ }_{17}$ Profesor A. Kwilecki, korzystając z zapisów ówczesnej Karty Nauczyciela, przeszedł - jako jedyny profesor uniwersytecki - na wcześniejszą emeryturę w wieku lat 60, uzasadniając swoją decyzję w sposób następujący: „[...] W latach osiemdziesiątych XX wieku zacząłem odczuwać wzrastające zmęczenie pracą organizacyjną i dydaktyczną na Uniwersytecie w warunkach napięć społecznych i politycznych zapoczątkowanych powstaniem »Solidarności«, wprowadzeniem stanu wojennego i pogłębiającym się kryzysem państwa. Tymczasem pracę naukowa, badawcza, pisarska, odwiedzanie bibliotek i archiwów traktowałem jako wytchnienie i odprężenie" - ibidem, s. $82-83$.

${ }^{18}$ Ze Wstepu, w: A. Kwilecki, Z pogranicza socjologii..., s. 7.

19 Artykuły publikowane były w latach 1993-2003 w „Głosie Wielkopolskim”, w cyklu: Ziemiaństwo Wielkopolskie.

20 Tenże przywracany świadomości społecznej świat zaprezentowany został w lipcu 2015 r. na warszawskiej wystawie zatytułowanej Europa $w$ rodzinie. Ziemiaństwo polskie $w$ XX wieku. Wystawę zorganizowano z inicjatywy warszawskiego i poznańskiego oddziału Instytutu Pamięci Narodowej, we współpracy z Polskim Towarzystwem Ziemiańskim i Zamkiem Królewskim w Warszawie. Wielkopolanie mogli obejrzeć tę wystawę w listopadzie 2015 r. w Muzeum Ziemiaństwa w Dobrzycy.

${ }^{21}$ Ziemianie polscy $w$ XX wieku, w: A. Kwilecki, Z pogranicza socjologii..., s. 142.

22 Recenzja książki Andrzeja Kwileckiego, Ziemiaństwo wielkopolskie, „Gazeta Wyborcza” z 4 stycznia 2002 r., poznan.wyborcza.pl/poznan/1,36000,627540.html [dostęp: październik 2016].

${ }^{23}$ Benefisantowi zadedykowała swój recital, występująca na scenach USA i Europy, polska mezzosopranistka Marta Wryk. 
ideom pracy organicznej i przybliżania Wielkopolanom dziedzictwa kulturowego ich regionu ${ }^{24}$.

$$
* * *
$$

Piszącego te słowa oprócz podziwu dla różnorodności tematyki badawczej i dorobku Profesora nurtuje narzucające się po lekturze promowanej książki pytanie, co chciał nam jej Autor jeszcze ważnego powiedzieć. Pewną podpowiedzią jest podtytuł publikacji: Elementy warsztatu badawczego. Otóż w charakterystyczny dla siebie, subtelny sposób prof. A. Kwilecki przypomniał współczesnym badaczom:

1) klasyczne, wielonarzędziowe instrumentarium socjologii, pomysłowe, twórcze wykorzystanie materiału jakościowego,

2) konieczność znajdowania balansu między tradycją i innowacyjnościa,

3) rolę kultury słowa i jasności przekazu,

4) wagę czujności i przenikliwości intelektualnej badacza życia społecznego, który pojawia się w odpowiednim miejscu i w odpowiednim czasie.

Warsztat naukowy A. Kwileckiego budzi szacunek i zawstydzać powinien zarazem tych socjologów, którzy na wypracowane wcześniej uniwersalne techniki i narzędzia badawcze nakładają obco brzmiące nazwy, mające dowodzić ich całkowitej nowości w socjologicznej „skrzynce z narzędziami”, deprecjonuja nieznane im techniki, wprowadzając odkrywcze, ich zdaniem, nazewnictwo geodezyjne (triangulacja) - jakby wcześniej urodzeni socjologowie nie wiedzieli, że należy porównywać badania prowadzone w różnych populacjach, w różnym czasie oraz w różnych miejscach i przez wielu badaczy, sięgających po różnorodne koncepcje teoretyczne tłumaczace zjawiska społeczne, stosujących wiele metod i technik badawczych. Wprowadzani do zawodu neofici, powielający jakoby zupełnie nowe sposoby zbierania i analizy materiału empirycznego, przypominają Molierowskiego pana Jourdaina, który nie wiedział, że mówi proza.

Socjologiczni „alchemicy słowa” większą wagę zdają się przypisywać samej narracji, atrakcyjnie brzmiącym terminom oraz tytułom artykułów i książek, niż podejmowaniu przedsięwzięć badawczych rozwijających dyscyplinę, a także przydatnych praktyce społecznej (np. badania funkcjonowania instytucji, państwa itp.). Polscy socjologowie fragmentarycznie „obsłużyli” tak ważne eksperymenty społeczne, jak transformacja ustrojowa, wejście do NATO i Unii Europejskiej.

Mając to wszystko na uwadze, mówię: Panie Profesorze! Chapeau bas!

prof. dr hab. Zbigniew Woźniak

Uniwersytet im. Adama Mickiewicza w Poznaniu

zbig@amu.edu.pl

${ }^{24}$ Prezydent RP Bronisław Komorowski w 2010 r. odznaczył prof. dr. hab. A. Kwileckiego Krzyżem Komandorskim Orderu Odrodzenia Polski „za wybitne zasługi w kultywowaniu tradycji narodowej, pielęgnowaniu polskości oraz w rozwijaniu świadomości narodowej, obywatelskiej i kulturowej”. W tym samym roku Kapituła Nagrody im. Ryszarda Kapuścińskiego wyróżniła Profesora za „konsekwentne, uczciwe i wsparte doskonałym aparatem badawczym przybliżanie dziedzictwa kulturowego Wielkopolski, wzbogacenie polskiej socjologii o badanie Ziem Zachodnich, pionierskie w Polsce studia poświęcone integracji europejskiej oraz postawę wierną ideom pracy organicznej”, natomiast w 2011 r. otrzymał statuetkę Starego Marycha, którą honorowane sa „osoby wierne wielkopolskim tradycjom i poznańskiemu etosowi pracy”. 


\section{THE CONVERGENCE OF EVENTS IN THE 'SEQUENCE OF SPECIAL CIRCUMSTANCES' AS A CATALYST INFLUENCING PROFESSOR ANDRZEJ KWILECKI'S RESEARCH INTERESTS}

\section{Summary}

The paper discusses the turning points in the career of the senior of Polish sociologist, Professor Andrzej Kwilecki, as they shaped his personality and decided upon his interest in the spheres of social life which at the same time coincided with the historical events of the twentieth-century history of Poland and Europe. 
